\title{
Review
}

\section{Carbon Farming: Prospects and Challenges}

\author{
Meenakshi Sharma ${ }^{1}$, Rajesh Kaushal ${ }^{2}$; Prashant Kaushik ${ }^{3^{*}}$ and Seeram Ramakrishna ${ }^{4^{*}}$
}

\author{
1 Department of Chemistry, Kurukshetra University Kurukshetra, Kurukshetra 136119, Haryana, India; \\ meenakshiskkr@gmail.com (M.S.) \\ 2 Division of Plant Science, ICAR-Indian Institute of Soil and Water Conservation, India; kaushalrajesh1@re- \\ diffmail.com (R.K.) \\ 3 Instituto de Conservación y Mejora de la Agrodiversidad Valenciana, Universitat Politècnica de València, \\ 46022 Valencia, Spain; \\ 4 Center for Nanotechnology and Sustainability, Department of Mechanical Engineering, National University \\ of Singapore 117576, Singapore \\ Correspondence: prashantumri@gmail.com (P.K.)*; Singapore seeram@nus.edu.sg (S.R.)
}

\begin{abstract}
Carbon farming is a capable strategy for more sustainable production of food and other related products. It seeks to produce the diverse array of natural farming methods and marketable products simultaneously. In agroforestry system, carbon sequestration is done by incorporating carbon dioxide (CO2) into plant biomass via photosynthesis. Carbon is, thus, stored in reserves of above-ground biomass, such as timber or branches, and below-ground biomass such as roots, or organic carbon in the soil. In addition to the significance of carbon sequestration in climate change mitigation, soil organic carbon (SOC) is an imperative indicator for the soil health as well as fertility. The change in SOC can explain whether the land use pattern degrades or improves the soil fertility. SOC, found in the soil in the form of soil organic matter (SOM), helps to improve soil health either directly or indirectly. Its direct consequence is related to the process of mineralization. Further, agroforestry is highly capable of generating huge amounts of bio-mass. In fact, agroforestry is believed to be particularly suitable for replenishment of SOC. Therefore, efforts should be made to convince farmers for their resource-use efficiency and soil conserving ability in order to get maximum benefits out of agriculture. According to food and agriculture organization $(F A O$,$) agriculture, forestry,$ and other land use practices account for $24 \%$ of global greenhouse gas (GHG) emissions, and total global livestock emissions of 7.1 gigatons of $\mathrm{CO} 2$-equivalent per year, representing $14.5 \%$ of total anthropogenic GHG emissions. Agroforestry system that deliberately integrates trees and crops with livestock in the agricultural production could potentially increase carbon sequestration and decrease GHG emission from the terrestrial ecosystems, thus, helping in global climatic change mitigation. This study, therefore, aimed at clarification about carbon farming, modifications in carbon cycle and carbon sequestration during agricultural development in addition to benefits of agroforestry.
\end{abstract}

Keywords: carbon farming; carbon foot printing; low carbon agriculture; carbon sequestration; carbon economy

\section{Introduction}

Novel approaches to cropping systems and soil management are being developed to cope with the abundance of $\mathrm{CO} 2$ in the environment, while at the same time improving water use efficiency and soil quality. In low-input areas, agroforests struggle to increase crop productivity and help farmers maintain soil quality. In combination with crops, particular tree species in agroforest-management systems may be feasible to provide solutions to numerous agricultural challenges [1,2]. The satisfaction of human needs and protection of environmental resources is key to effective planning strategies. Different management practices are known to affect the amount of soil organic matter, the soil composition, and water retention capacity [3,4]. Soil quality research aims to understand how 
to manage soil to take advantage of its inherent qualities in the environment. It is necessary to recognize the various factors that affect the health of the soil, among which organic matter is critically important [5,6]. Easily manipulated by land management activities, organic matter is found in most of the agricultural settings. As organic matter increases the ability to retain water and strengthens the soil structure $[7,8]$, it increases agricultural productivity along with the environment's resistance to drought and disease while simultaneously reducing the costs and the impact of epidemics [9,10]. Agricultural activities that deposit organic matter into the vegetation, are necessary in order to limit the environmental CO2 [11,12]. It has been demonstrated that activities related to soil management are essential in conserving and restoring soil carbon. However, many, though not all, farming fields on the planet have substantial carbon deficiency because of soil erosion and breakdown $[13,14]$. It is widely accepted that various governments employ measures to curb this practice and incentivize the use of ecologically sustainable methods. Another government project is the implementation of environmental policies that attempt to maintain a low carbon footprint. In addition to traditional tillage, terracing, and no-mulching systems, farmers are advised to use other systems such as biofertilizers, no-till, and vegetal mulch, along with systems operating under agroforestry $[15,16]$.

Forests are essential for maintaining biodiversity. Deforestation has a substantial impact on the flow of rivers and land use pattern $[17,18]$. Agriculture, forestry, and other land use practices account for 24 percent of global greenhouse gas (GHG) emissions, with total global livestock emissions of 7.1 gigatonnes of $\mathrm{CO} 2$-equivalent per year, accounting for 14.5 percent of total anthropogenic GHG emissions, according to the Food and Agriculture Organization (FAO) [19]. Therefore, planning and management of the forests must consider how they relate to other aspects of ecosystem. Further, there is a significant scope for net reduction in global warming as a consequence of $\mathrm{CO} 2$ sequestration [20]. Although injecting flue gas into aquifers poses the risk of carbon leakage over time, it offers little economic advantage, this carbon sequestration technique is more attractive [21,22]. Microalgae exhibit a highly productive photosynthesis, resulting in the release of large amounts of $\mathrm{CO} 2$ as organically bound carbon and accumulating it in their cells [23,24]. And if biomass was sourced from fossil fuels, $\mathrm{CO} 2$ pollution per unit would be lowered due to the $\mathrm{CO} 2$ that is recycled and then reused by algae [25].

\section{Carbon Foot Printing}

Carbon footprint (CF) is a measurement of total product or system balance of GHG emissions and drops over the course of the product or system life [26]. A CF takes all inputs and processes within the confines of a defined system into account. The friction coefficient is calculated within a system limit, a hypothetical line based on the activity and materials used to calculate the friction coefficient [27]. While the findings of CF research may provide useful information in order to make effective choices the methods used to calculate CF for agricultural systems are at present lacking in consistency [28]. In several areas, consistency is missing, including the choice of functional units, system limits and emission factor specificity (EFS). If carbon is absorbed into the earth, it could significantly impact agricultural emissions of carbon dioxide (CO2) [29]. Adewale et al. quantified carbon loss and gain in soil, and found that $13 \%$ of CF net soil emissions were produced from small production of vegetables [30]. Therefore, a full assessment must cover carbon (CO2 or sequestered), on the net GHG emissions of a particular farm or farm product or field operations [31]. This is important to determine whether agricultural techniques can help implement a GHG reduction strategy successfully.

However, it is difficult for a variety of reasons to estimate soil GHG emissions from diverse farm activity. There are significant variations amongst other factors in soil carbon (C), global and field-scale estimates [32]. In addition, the dynamics and interaction of labile and re-calcitrant carbon stores give a combined effort to develop consistent methods and models for site-specific information. Organic agriculture is a beneficial subset of CF agriculture since it requires the conservation or improvement of natural resources along 
with annual certification [33]. Numerous studies were carried out to determine the environmental impact of organic farming, most of which demonstrate advantages over conventional farming methods [34,35]. Organic farming, thus, offers a number of advantages per unit area, including increased soil content, lowering nutrient performance and lower consumption of energy [36].

However, whether organic farming produces more or less greenhouse gas emissions than conventional farming is not definitely answered since the findings vary by product and farm. According to a study, organic farming techniques emit more ammonia, nitrogen and N2O per Product Unit than conventional farming systems [37]. Organic dairy and organic pig farmers are often responsible for more GHG emissions by unit than conventional systems, while organic beef production generates fewer GHG emissions per kilogram meat [38]. However, due to a large number of results, conclusions cannot be drawn regarding the CF of the different systems. Many studies advocate the use of Tier3 EFS to improve the precision and usefulness of methods of estimating agricultural GHGs [39]. As a result of the study, the case for the broad and consistent agricultural CF limits, including the inclusion of soil and carbon sequestration and the establishment of new agricultural EFS Tier 3 has been established and reinforced [39]. Given the potential to contribute significantly to GHG reduction efforts by organic fertilizers and technology, it is critically needed that Tier $3 \mathrm{EFs}$, particularly for organic inputs, be established. The limits of the agricultural system should include farm infrastructure and machinery, pesticides and other chemical inputs, soil-use changes, soil emissions and sequestration of carbon and livestock enteric fermentation, in combination with more traditional inputs such as fertilizer, fuel and electricity [40]. Any such factor could be critical in determining systems differentiation or the most effective strategies for $\mathrm{CF}$ prevention and reduction. Furthermore, agricultural operations need adequate monitoring so that farmers can make informed decisions regarding equipment and use of fuel and soil carbon changes [41]. Organic farming frequently has a lower carbon footprint (CF) than conventional agriculture when measured by area and sometimes by product unit [31]. The future use of certified organic farms as a longitudinal national or global population study will be justified due to the potential benefits and the annual inspection and certification process. In this direction, representative concentration pathway $(\mathrm{RCP})$ is a greenhouse gas concentration trajectory approved by the Intergovernmental Panel on Climate Change (IPCC). In 2014, the IPCC's fifth assessment report took four distinct paths in climate modelling and research[42]. The paths illustrate possible climate futures, and each is considered plausible considering $\mathrm{CO} 2$ generated in the coming years. RCP2.6, RCP4.5, RCP6, and RCP8.5 refer to radiative forcing values for the year 2100 (Figure 1).

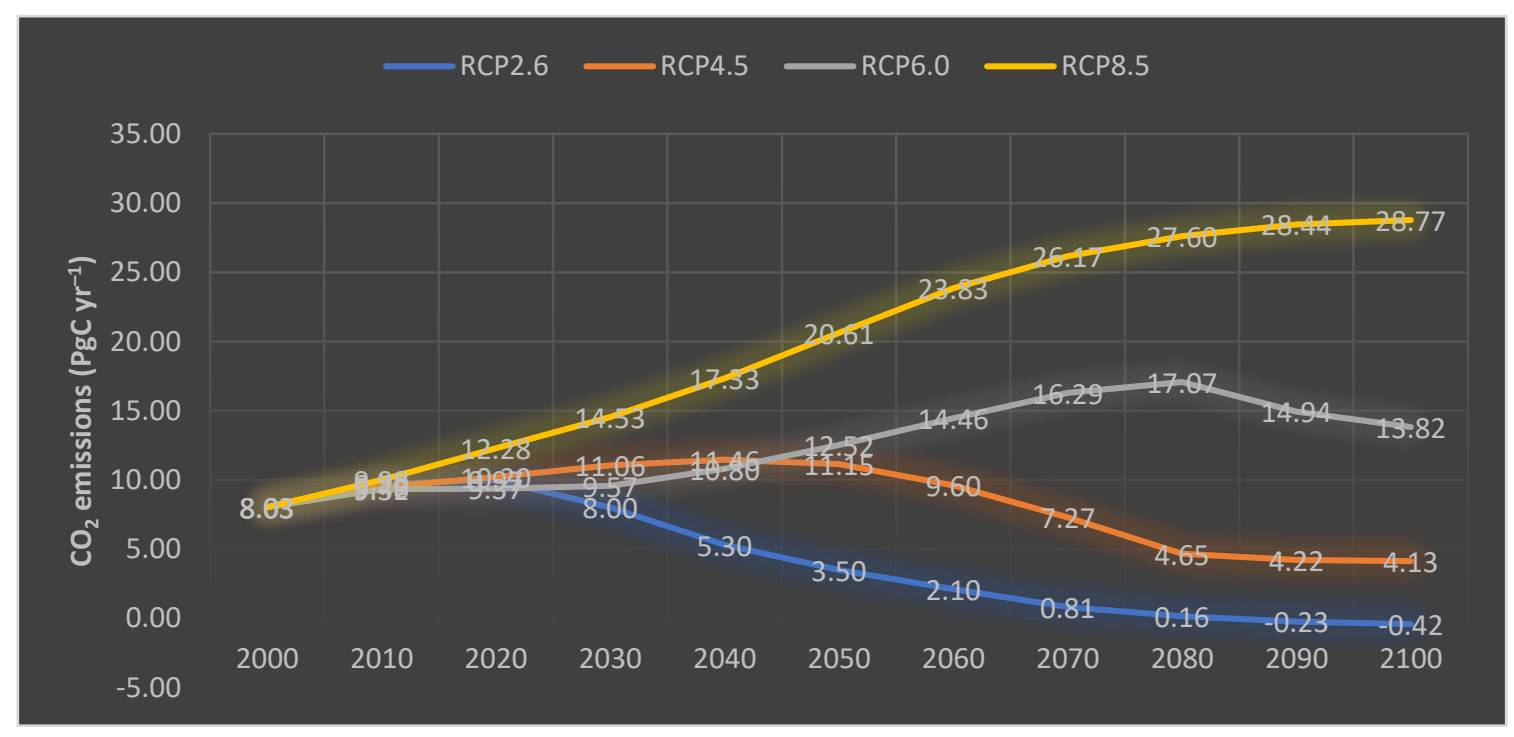

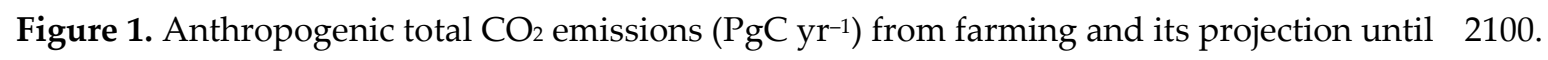




\section{Low Carbon Agriculture}

In hot regions, organic matter tends to be quickly degraded, with corresponding changes in the chemical, physical, and biological composition [43]. In these regions, appropriate soil conservation and crop management is predicated on using little or no-tillage, with those crops that are higher on residue production [44,45]. Minimal soil disturbance, consistent soil coverage, and crop rotation are part of the conservation practices [46]. Management systems that include plantations, tree crops, and pastures must be applied to this context. Restoration systems have proven successful because of their capacity to improve soil and biomass stores in the long term [47]. Agro-forestation has proven useful in creating environmental, economic, and ecological value for agricultural areas in temperate and tropical ecosystems [48]. These may include increases in nutrient utilization and irrigation, creation of habitats for plants, insects, and animals; and protection from erosion in hilly locations $[49,50]$. Litter and tree roots constitute the highly sustainable way of formation as well as enhancing the quality of soil organic matter (SOM) in agroforestry ecosystems [51,52]. However, soil fertility is distinct in tropical agroforests, where they tend to have low organic matter due to high porosity and depth $[53,54]$. According to their availability, the management of diverse plant species allocating nutrients at varying levels, allows for sustainable nutrient management in nutrient-depleted soils $[55,56]$.

An agro-forestation system combines trees and grassland farming. The trees are used to make quality wood products while also providing forage and shelter. Most treeless savanna systems can sequester carbon, as well as extract or remediate nutrients [57]. On the other hand, grassland areas can serve to preserve the biodiversity [58]. Advantages to reduced silviculture practices, include greater carbon sequestration and enhanced nutrient removal. Alley cropping has been used in both temperate and tropical regions to grow trees and coffee, cocoa, and livestock [59,60]. Cultivated vegetation in alley cropping systems has been shown to improve soil nutrient cycling [61], reduce nutrient losses [62], promote fauna activity [63], enhance fertility [64], and control soil erosion [65]. Interest in developing alleys as alternative crops and as a carbon sink has risen because of the development of species like Robinia pseudoacacia, also as a great potential to offset greenhouse gas emissions [66]. Improving soil characteristics due to N2 fixation and increasing SOM in the litterfall may contribute to R. pseudoacacia's overall success $[67,68]$.

However, some researchers have suggested that alley cropping systems can replace soil use [69]. The labile organic fraction also decreased with the continued use of alley cropping $[64,70]$. The research needs to be done in order to discover the possible impacts of agroforests on tropical soils. Also, studies of the alley's forest or annual litterfall and non-tree elements of alley-based agriculture should be done. Integrating three elements (farming, livestock, and forestry), with various conservation practices aims to revitalize soils while increasing carbon sequestration in long-term [71,72]. In a crop-livestock system, forests are involved simultaneously as livestock-grazing land after the crops have been harvested. Moreover, an integrated crop-livestock-forest system may improve soil biodiversity, nutrient depletion, and nutrient recycling, as withstanding capacities [73,74]. These systems maximize total production, lower the total risk, and increase the cultivation alternatives, rendering them economically favourable to monoculture $[73,75]$.

\section{Effects of Plant Residue Quality on Carbon Dynamics}

The amount, location and bio-degradability of the plant residues can significantly affect soil organic carbon [76,77]. Therefore, the added plant residue is important in different ecosystems, along with microbial biomass, mineralization, and organic matter production rates [78,79]. The quality of plant residues, weather and soil mineralogy, such as acidity, biological readiness and mineral contents, are mainly determined by the rates of residual mineralization $[80,81]$. The management of plant residues has been found to increase the processing of biological nutrients and minerals. Plant species with distinct abilities are especially important for agricultural systems with limited fertilizer input $[82,83]$. The residue is affected by the variations in chemical and biochemical characteristics 
$[84,85]$. In addition, the composition of residue mineraux and their chemical profile in controlled environments decides the extent of decomposition or in other words, the biochemical composition of residue controls the rate of decomposition [86,87]. However, plant residue management alone may not be sufficient to ensure enough carbon reserves in the soil, it is associated with the physical soil structure also [88,89]. The soil carbon levels decreased considerably as a result of conversion of the forest land to agricultural land $[90,91]$. The loss in soil inputs, nutrients and its decomposition can be attributed to changes in forest carbon, and ecosystem disturbance [92,93].

The carbon isotope composition in the soil is a useful technique for quantifying the rate of organic and/or nonbiological processes [94]. A number of ecosystems have been investigated using $\mathrm{C}$-isotopic techniques for SOM concentrations. Most of these studies have investigated the $13 \mathrm{C}$ (isotopic) properties of SOM that have emerged through vegetation changes between the C3 plants and the C4 plants [95,96]. Depending on the location and environmental exposure, there are different results. Changes in the $13 \mathrm{C}$ concentration of these fractions can thus tell us about SOM consumption rates and provide useful information about the different control systems of management. The crucial point is that the natural wealth and quantity data must be tracked for each of the system components. Some examples have been used for agricultural ecosystems of $13 \mathrm{C}$ stable isotope analyses $[97,98]$. The scientists found that the maintenance of trees led to substantial improvements in the sequestration of carbon in the long run $[99,100]$. In conventional agriculture, it was discovered that soil water depletion was greater in the alley than in the trees $[69,101]$.

\section{Carbon Sequestration}

There has been an increased interest in carbon sequestration techniques as a matter of environmental concern about global warming and $\mathrm{CO} 2$ emissions. Human activity has an effect on the terrestrial carbon cycle (approximately 50\% CO2 sequestration) both directly and indirectly [102,103]. CO2 emissions are commonly believed to be caused by the burning of fossil fuels $[104,105]$. With demand for energy increasing rapidly, particularly in developing countries, CO2 emissions are expected to increase even more. The overwhelming body of scientific evidence indicates that elevated $\mathrm{CO} 2$ levels in the atmosphere are detrimental to the environment [106,107]. According to the researchers, increased CO2 levels produces greenhouse effect, resulting in increased temperatures and hence global warming $[108,109]$. Each year, the oceans absorb about a quarter of all the anthropogenic CO2 emissions [110,111]. This could be beneficial, but at a cost since increased CO2 levels in seawater rise, forming carbonic acid [112,113]. There have been numerous evidences to suggest that ocean acidity has increased by $30 \%$ since the industrial revolution began. Increased water acidity impairs the development of marine shells and skeletons, primarily affecting deep-sea organisms such as benthic and anadromous fauna [111,112]. Additional increases in oceanic acidity are believed to hasten the demise of marine life. Therefore, to meet the energy demand while minimizing $\mathrm{CO} 2$ emissions, stringent post-combustion carbon sequestration management will be required.

Carbon capture and storage is a process that absorbs $\mathrm{CO} 2$ from flue gaseous emissions and stores it for extended periods of time [114,115]. Carbon sequestration is defined as the deliberate or intentional separation and disposal of $\mathrm{CO} 2$ as a by-product of combustion in non-atmospheric reservoirs [116]. It has been defined as the process of increasing natural processes, such as CO2 absorption by living organisms, in order to offset any additional CO2 emitted [21,117]. Organic carbon can be produced by autotrophic organisms and plants through photosynthesis, which involves the reduction of CO2 $[118,119]$. Carbon is found in all biological media, including peat and seawater $[120,121]$. It is incorporated into the cells of these organisms via photosynthesis. Thus, appropriate carbon management is necessary to ensure that biomass can be used for a variety of commercial purposes while also sequestering sufficient carbon in biological media to keep the air safe. Energy crops such as biofuels may be used in a variety of ways, for instance, as a biofuel, fertilizer, food, and animal feed [122,123]. CO2 can be recycled during the biofuel 
production process, and biomass may be used in place of fossil fuels [124,125]. This method enables the harvesting of a significant amount of $\mathrm{CO} 2$-rich flue gas for cultivation. If the process is carried out properly, these will result in massive amounts of value-added biomass and materials that can be further used to make bio-ethanol. The issues surrounding $\mathrm{CO} 2$ recovery from point sources, as well as the legislative and policy drivers must be examined in order to get maximum benefit. The biological carbon mitigation technology (BCM) in CO2 sequestration has been discussed in detail, as is the applicability of microalgae [21,126]. To ascertain the fate of mitigated carbon, the commercial applications of BCM technology are being investigated.

\section{Carbon cycle in agriculture}

The main sources of carbon circulating actively are atmospheric CO2, biomass (generally vegetation), soil organic matter, and the oceans [127,128]. Among these, the oceans are known to comprise the largest carbon reserves, however most of the carbon lies in deep ocean-layers (not involved in active carbon circulation) (Alves et al., 2018; Cheah et al., 2015). Carbon stocks in biomass or biota are less certain to some extent, however, they are almost equivalent to the atmospheric sources [131]. About 75\% of this, is found in forests [132]. Plants found in the ocean, mostly algae, possess less than $1 \%$ global carbon biomass [133]. The largest source of carbon circulating actively in the terrestrial ecosystem is the soil [134]. It contains carbon in different organic forms, such as plant litter or charcoal or fossils [135]. About one third of the organic carbon in soil is found in forests, another one third in savannas and grasslands, and the rest part in wetlands, and other biomes [136].

All of these carbon sources, viz. the atmosphere, the vegetation, the soil, and the oceans are interconnected. Atmospheric CO2 follows photosynthesis to enter terrestrial bio-mass, however, almost half of the $\mathrm{CO} 2$ is released through respiration in plants [137]. The amount of CO2 left or net primary production (NPP) is stored provisionally in vegetative tissues, which eventually enters the soil after attaining senescence [138]. Simultaneously, heterotrophic respiration performed mainly by soil micro-organisms and other anthropogenic activities return roughly equivalent amount of NPP back to the atmosphere, closing the loop [138]. CO2 exchange between the atmosphere and the ocean is even larger. Some of this occurs by physical processes, involving the CO2-carbonate equilibria, but a surprisingly large exchange also occurs via biological processes [139].

\section{Challenges in carbon farming}

The carbon farming initiatives (CFI) demands for agro-environmental policies to incentivize farmers to adopt best farm management practices. However, it is usually difficult to get farmer's involvement in such programs mainly because of the complex schemedesign along with its implementation, or conflicting targets of policy-makers and the farmers [140]. Various factors are known to affect the adoption and implementation of new farm management practices which include personal interests of landholders, farm or land features [141,142]. Some of the barriers in carbon farming directly associated with the landholders' interests, along with inadequate skills or management abilities for the implementation of carbon farming programs or practices. Political instability also substantially affects the acceptance and implementation of such practices [143]. Uncertainty about environment related schemes and policies may significantly undermine their adoption, and may be aggravated by lack of awareness or knowledge of the concerned program $[144,145]$.

It has been agreed by farmers that they have insufficient access to information regarding available options for carbon farming [145,146]. In fact, many farmers don't understand the exact meaning of carbon farming and they lack detailed information about pros and cons of carbon farming. This was further exaggerated by high input costs, and apprehensions regarding the effect of carbon farming on yield and farm productivity. Other major barriers in CFI were lack of approved methods and procedures, higher 
administrative expenses, and difficulty in getting certification as a qualified carbon-offset provider [147,148]. In addition, the capital investment required for adopting new farm management strategies, unsuitability of carbon farming with existing farm management practices, and the probable impacts on the ability of farmers to obtain financial assistance from banks or other sources have been identified as important challenges to carbon farming $[145,149]$.

Besides, other barriers that need specific mention include: instability in carbon prices [150]; uncertainty regarding benefits from carbon farming [151]; difficulty in measurements or monitoring the progress [152]; uncertainty regarding carbon market selling practices [153]; and the financial consequences of participation [154]. Farmers also stated that the sale of properties with tree plantations are difficult which indicates their reluctance to implement carbon farming as they consider it to be dissenting with other objectives $[146,148]$. The encouragement through financial incentives for increased participation in CFI does not seem to be sufficient to tackle the barriers that farmers generally face. Moreover, some farmers believe that the carbon farming policy rewards them with an antiquity of improper land management, which further prevents their involvement $[155,156]$. This suggests that farmer's personal interests or sentiments may offer a participation barrier to CFI, along with the other barriers mentioned above.

\section{Carbon economy}

Instead of colonizing the governance spaces created by calculating a product's carbon footprint, retailers are establishing new regimes of corporate responsibility requirements to measure and manage carbon emissions in which certain behaviours are encouraged, legitimized, and/or eliminated in order to force individual supply chain partners to become active participants in their own governance $[157,158]$. In this case carbon reduction, with the values and ambitions of their supply chain partners [159,160]. Suppliers at all levels and tiers of a product's supply chain are encouraged to collect and share their best carbon footprint data [161,162]. While global retailers assume responsibility for creating the market conditions and infrastructure (e.g., the tools), and have presumably received platitudes for their role in mitigating climate change, the actual delivery of these climate change mitigation programmes and risk associated with them is positioned as the specific responsibility of the government [158]. This exportation of climate mitigation duty and risk across a product's supply chain, with merchants achieving their headline-grabbing objectives at the expense of their workforces now ensconced in new accountability regimes [158,163].

With respect to climate change, retailers take on a larger and more extensive role in measuring and reducing the carbon footprint of the products in order to strengthen their place in society, ensuring their long-term viability and licence to operate [164]. By taking this approach, retailers have sparked a radical reimagining of the carbon economy due to their size and ubiquity at the intersection of daily consumption-production practices $[158,164]$. Retailers reframe what their supply chains must care about by looking beyond their direct operations to the entire life cycle of their product through product carbon foot printing, introducing new norms and priorities into existing and new relationships $[165,166]$. In contrast to previous models of supply chain responsibility, the footprint is established as a regime of responsibilities in which suppliers assume self-governance and retailers enact measurement, reductions, and, ultimately, governance of their supply chain behaviours [167]. In the case of product carbon foot printing, suppliers have independently adopted new measurement techniques, collected and disclosed data, and made carbon reductions.

The product carbon footprint responsibility could be a potentially new tool for retailers and other leaders to empower their suppliers to take responsibility for the water, waste, and ultimately environmental and social impacts embedded in the products they deliver to the next stage of the supply chain $[168,169]$. The priorities established, ambitions set, and responsibilities assumed by multinational corporations have a profound impact 
on the lives of consumers, suppliers, society, and global ecologies. From halting deforestation to reducing carbon emissions, multinational corporations' priorities, ambitions, and responsibilities radically affects the lives of suppliers, consumers, society, and global ecologies at large $[158,170]$. In the absence of well-defined and well-enforced international environmental standards, these actors are increasingly defining sustainability in corporate terms [171]. When it comes to mitigating climate change, this has resulted in retailers gradually reimagining the transition to a low-carbon economy in ways that align with their commercial and risk-averse interests $[163,172]$. However, there is an unavoidable risk of failing to truly tackle the more fundamental questions relating to consumption, at the root of global environmental changes, as well as the rapidly consolidating and expanding power of these now sustainable corporate citizens in the process of creating a market for low-carbon products.

\section{Conclusion:}

Agroforestry has developed as an all-inclusive land-use management practice beneficial for both environment and the society. Combination of forest vegetation with crop farming and livestock production through agroforestry improves net agricultural production, along with food security. GHG emissions and carbon sequestration in agroforestry depend upon many biophysical and biochemical factors including climate conditions, soil characteristics, water management, vegetation, and the land use management practices. However, silvo-pastoral system was generally found to be more effective in relation to both carbon sequestration and GHG emissions reduction as compared to the agroforestry system which includes annual cropland farming. Interventions such as enrichment planting along with organic amendments of the soil to prevent the release of nutrients are also site-specific for their effectiveness. Agroforestry ecosystems might be estimated with various environmental indicators depending upon the energy use, the yield and productivity, and the production processes. There is a great possibility of implementing environmentfriendly practices of cultivation in agricultural productions. Moreover, the agricultural production resilience on climatic change can be stabilized by using less-intensive and judiciously organized methods of farming. In this context, the above mentioned agro-environmental parameters may prove useful to decision-makers looking for farming systems which can control the delicate balance between climatic change and agricultural productions. Advisory services should be provided to farmers to encourage them to adopt soil or land management and tree planting practices, and to reduce the unsustainable practices. In conclusion, agroforestry systems are highly efficient at retaining organic carbon stocks in the soil. These systems are capable of accumulating greater amounts of soil organic carbon stocks as compared to mono-cropping, thereby improving soil quality.

Author Contributions: R.K. and P.K. conceived of and designed the project; P.K. and S.R. supervised the study; M.S., R.K. and P.K. wrote the paper; R.K., S.R. and P.K. checked and corrected the final draft. All authors have read and agreed to the published version of the manuscript.

Funding: This research received no external funding.

Institutional Review Board Statement: Not applicable.

Informed Consent Statement: Not applicable.

Data Availability Statement: Not applicable.

Conflicts of Interest: The authors declare that no conflict of interest exist. 


\section{References:}

1. Dewi, S.; Van Noordwijk, M.; Zulkarnain, M.T.; Dwiputra, A.; Hyman, G.; Prabhu, R.; Gitz, V.; Nasi, R. Tropical ForestTransition Landscapes: A Portfolio for Studying People, Tree Crops and Agro-Ecological Change in Context. International Journal of Biodiversity Science, Ecosystem Services \& Management 2017, 13, 312-329.

2. Nair, P.K.R. Carbon Sequestration Studies in Agroforestry Systems: A Reality-Check. Agroforestry systems 2012, 86, $243-253$.

3. Aranda, V.; Ayora-Cañada, M.J.; Dominguez-Vidal, A.; Martin-Garcia, J.M.; Calero, J.; Delgado, R.; Verdejo, T.; González-Vila, F.J. Effect of Soil Type and Management (Organic vs. Conventional) on Soil Organic Matter Quality in Olive Groves in a Semi-Arid Environment in Sierra Mágina Natural Park (S Spain). Geoderma 2011, 164, 54-63.

4. Fageria, N.K. Role of Soil Organic Matter in Maintaining Sustainability of Cropping Systems. Communications in Soil Science and Plant Analysis 2012, 43, 2063-2113.

5. Bolan, N.S.; Adriano, D.C.; Kunhikrishnan, A.; James, T.; McDowell, R.; Senesi, N. Dissolved Organic Matter: Biogeochemistry, Dynamics, and Environmental Significance in Soils. Advances in agronomy 2011, 110, 1-75.

6. Scotti, R.; Bonanomi, G.; Scelza, R.; Zoina, A.; Rao, M.A. Organic Amendments as Sustainable Tool to Recovery Fertility in Intensive Agricultural Systems. Journal of soil science and plant nutrition 2015, 15, 333-352.

7. Karami, A.; Homaee, M.; Afzalinia, S.; Ruhipour, H.; Basirat, S. Organic Resource Management: Impacts on Soil Aggregate Stability and Other Soil Physico-Chemical Properties. Agriculture, Ecosystems E Environment 2012, 148, $22-28$.

8. Tisdall, J.M. Formation of soil aggregates and accumulation of soil organic matter. In Structure and organic matter storage in agricultural soils; CRC Press, 2020; pp. 57-96.

9. Altieri, M.A.; Nicholls, C.I.; Henao, A.; Lana, M.A. Agroecology and the Design of Climate Change-Resilient Farming Systems. Agronomy for sustainable development 2015, 35, 869-890.

10. Garrett, K.A.; Forbes, G.A.; Savary, S.; Skelsey, P.; Sparks, A.H.; Valdivia, C.; Van Bruggen, A.H.C.; Willocquet, L.; Djurle, A.; Duveiller, E. Complexity in Climate-Change Impacts: An Analytical Framework for Effects Mediated by Plant Disease. Plant Pathology 2011, 60, 15-30.

11. Hartmann, J.; West, A.J.; Renforth, P.; Köhler, P.; De La Rocha, C.L.; Wolf-Gladrow, D.A.; Dürr, H.H.; Scheffran, J. Enhanced Chemical Weathering as a Geoengineering Strategy to Reduce Atmospheric Carbon Dioxide, Supply Nutrients, and Mitigate Ocean Acidification. Reviews of Geophysics 2013, 51, 113-149.

12. Mcleod, E.; Chmura, G.L.; Bouillon, S.; Salm, R.; Björk, M.; Duarte, C.M.; Lovelock, C.E.; Schlesinger, W.H.; Silliman, B.R. A Blueprint for Blue Carbon: Toward an Improved Understanding of the Role of Vegetated Coastal Habitats in Sequestering CO2. Frontiers in Ecology and the Environment 2011, 9, 552-560.

13. Kirkels, F.; Cammeraat, L.H.; Kuhn, N.J. The Fate of Soil Organic Carbon upon Erosion, Transport and Deposition in Agricultural Landscapes-A Review of Different Concepts. Geomorphology 2014, 226, 94-105.

14. Xiao, H.; Li, Z.; Chang, X.; Huang, B.; Nie, X.; Liu, C.; Liu, L.; Wang, D.; Jiang, J. The Mineralization and Sequestration of Organic Carbon in Relation to Agricultural Soil Erosion. Geoderma 2018, 329, 73-81.

15. Chapagain, T.; Raizada, M.N. Agronomic Challenges and Opportunities for Smallholder Terrace Agriculture in Developing Countries. Frontiers in plant science 2017, 8, 331.

16. Chhabra, V.; Abdul Haris, A.; Prakash, V.; Upadhyay, H. CROPPING SYSTEMS AND THEIR EFFECTIVENESS IN ADAPTATION AND MITIGATION OF CLIMATE CHANGE. Plant Archives 2018, 18, 1175-1183.

17. Liu, Y.; Zhang, X.; Xia, D.; You, J.; Rong, Y.; Bakir, M. Impacts of Land-Use and Climate Changes on Hydrologic Processes in the Qingyi River Watershed, China. Journal of Hydrologic Engineering 2013, 18, 1495-1512.

18. Tan, M.L.; Ibrahim, A.L.; Yusop, Z.; Duan, Z.; Ling, L. Impacts of Land-Use and Climate Variability on Hydrological Components in the Johor River Basin, Malaysia. Hydrological Sciences Journal 2015, 60, 873-889. 
19. FAO - News Article: Key Facts and Findings Available online: http://www.fao.org/news/story/en/item/197623/icode/ (accessed on 23 July 2021).

20. Powlson, D.S.; Whitmore, A.P.; Goulding, K.W. Soil Carbon Sequestration to Mitigate Climate Change: A Critical ReExamination to Identify the True and the False. European Journal of Soil Science 2011, 62, 42-55.

21. Farrelly, D.J.; Everard, C.D.; Fagan, C.C.; McDonnell, K.P. Carbon Sequestration and the Role of Biological Carbon Mitigation: A Review. Renewable and sustainable energy reviews 2013, 21, 712-727.

22. Zheng, J.; Chong, Z.R.; Qureshi, M.F.; Linga, P. Carbon Dioxide Sequestration via Gas Hydrates: A Potential Pathway toward Decarbonization. Energy \& Fuels 2020, 34, 10529-10546.

23. Bhola, V.; Swalaha, F.; Kumar, R.R.; Singh, M.; Bux, F. Overview of the Potential of Microalgae for CO 2 Sequestration. International Journal of Environmental Science and Technology 2014, 11, 2103-2118.

24. Singh, S.K.; Sundaram, S.; Sinha, S.; Rahman, M.A.; Kapur, S. Recent Advances in CO2 Uptake and Fixation Mechanism of Cyanobacteria and Microalgae. Critical reviews in environmental science and technology 2016, 46, 1297-1323.

25. Moreira, D.; Pires, J.C. Atmospheric CO2 Capture by Algae: Negative Carbon Dioxide Emission Path. Bioresource technology 2016, 215, 371-379.

26. Pérez, J.; Lumbreras, J.; Rodríguez, E.; Vedrenne, M. A Methodology for Estimating the Carbon Footprint of Waste Collection Vehicles under Different Scenarios: Application to Madrid. Transportation Research Part D: Transport and Environment 2017, 52, 156171.

27. Sundarakani, B.; De Souza, R.; Goh, M.; Wagner, S.M.; Manikandan, S. Modeling Carbon Footprints across the Supply Chain. International Journal of Production Economics 2010, 128, 43-50.

28. Rebolledo-Leiva, R.; Angulo-Meza, L.; Iriarte, A.; González-Araya, M.C. Joint Carbon Footprint Assessment and Data Envelopment Analysis for the Reduction of Greenhouse Gas Emissions in Agriculture Production. Science of the Total Environment 2017, 593, 36-46.

29. Liu, X.; Zhang, S.; Bae, J. The Impact of Renewable Energy and Agriculture on Carbon Dioxide Emissions: Investigating the Environmental Kuznets Curve in Four Selected ASEAN Countries. Journal of cleaner production 2017, 164, $1239-1247$.

30. Adewale, C.; Higgins, S.; Granatstein, D.; Stöckle, C.O.; Carlson, B.R.; Zaher, U.E.; Carpenter-Boggs, L. Identifying Hotspots in the Carbon Footprint of a Small Scale Organic Vegetable Farm. Agricultural Systems 2016, 149, 112-121, doi:10.1016/j.agsy.2016.09.004.

31. Adewale, C.; Reganold, J.P.; Higgins, S.; Evans, R.D.; Carpenter-Boggs, L. Improving Carbon Footprinting of Agricultural Systems: Boundaries, Tiers, and Organic Farming. Environmental Impact Assessment Review 2018, 71, 41-48.

32. Paustian, K.; Collier, S.; Baldock, J.; Burgess, R.; Creque, J.; DeLonge, M.; Dungait, J.; Ellert, B.; Frank, S.; Goddard, T. Quantifying Carbon for Agricultural Soil Management: From the Current Status toward a Global Soil Information System. Carbon Management 2019, 10, 567-587.

33. Padmavathy, K.; Poyyamoli, G. Alternative farming techniques for sustainable food production. In Genetics, Biofuels and Local Farming Systems; Springer, 2011; pp. 367-424.

34. Gomiero, T.; Pimentel, D.; Paoletti, M.G. Environmental Impact of Different Agricultural Management Practices: Conventional vs. Organic Agriculture. Critical reviews in plant sciences 2011, 30, 95-124.

35. Pimentel, D.; Burgess, M. An environmental, energetic and economic comparison of organic and conventional farming systems. In Integrated Pest Management; Springer, 2014; pp. 141-166.

36. Tuomisto, H.L.; Hodge, I.D.; Riordan, P.; Macdonald, D.W. Does Organic Farming Reduce Environmental Impacts?-A MetaAnalysis of European Research. Journal of environmental management 2012, 112, 309-320.

37. Clark, M.; Tilman, D. Comparative Analysis of Environmental Impacts of Agricultural Production Systems, Agricultural Input Efficiency, and Food Choice. Environmental Research Letters 2017, 12, 064016. 
38. Cederberg, C.; Hedenus, F.; Wirsenius, S.; Sonesson, U. Trends in Greenhouse Gas Emissions from Consumption and Production of Animal Food Products-Implications for Long-Term Climate Targets. Animal 2013, 7, 330-340.

39. Flynn, H.C.; Canals, L.M.I.; Keller, E.; King, H.; Sim, S.; Hastings, A.; Wang, S.; Smith, P. Quantifying Global Greenhouse Gas Emissions from Land-Use Change for Crop Production. Global Change Biology 2012, 18, 1622-1635.

40. Zuazo, V.H.D.; Pleguezuelo, C.R.R.; Flanagan, D.; Tejero, I.G.; Fernández, J.L.M. Sustainable land use and agricultural soil. In Alternative Farming Systems, Biotechnology, Drought Stress and Ecological Fertilisation; Springer, 2011; pp. 107-192.

41. Capalbo, S.M.; Antle, J.M.; Seavert, C. Next Generation Data Systems and Knowledge Products to Support Agricultural Producers and Science-Based Policy Decision Making. Agricultural systems 2017, 155, 191-199.

42. van Vuuren, D.P.; Edmonds, J.A.; Kainuma, M.; Riahi, K.; Weyant, J. A Special Issue on the RCPs. Climatic Change 2011, 109, 1-4, doi:10.1007/s10584-011-0157-y.

43. Burd, A.B.; Frey, S.; Cabre, A.; Ito, T.; Levine, N.M.; Lønborg, C.; Long, M.; Mauritz, M.; Thomas, R.Q.; Stephens, B.M. Terrestrial and Marine Perspectives on Modeling Organic Matter Degradation Pathways. Global change biology 2016, 22, 121-136.

44. Vincent-Caboud, L.; Peigné, J.; Casagrande, M.; Silva, E.M. Overview of Organic Cover Crop-Based No-Tillage Technique in Europe: Farmers' Practices and Research Challenges. Agriculture 2017, 7, 42.

45. Williams, J.D.; Wuest, S.B.; Long, D.S. Soil and Water Conservation in the Pacific Northwest through No-Tillage and Intensified Crop Rotations. Journal of Soil and Water Conservation 2014, 69, 495-504.

46. Sun, L.; Wang, S.; Zhang, Y.; Li, J.; Wang, X.; Wang, R.; Lyu, W.; Chen, N.; Wang, Q. Conservation Agriculture Based on Crop Rotation and Tillage in the Semi-Arid Loess Plateau, China: Effects on Crop Yield and Soil Water Use. Agriculture, Ecosystems \& Environment 2018, 251, 67-77.

47. Ward, E.B.; Doroski, D.A.; Felson, A.J.; Hallett, R.A.; Oldfield, E.E.; Kuebbing, S.E.; Bradford, M.A. Positive Long-Term Impacts of Restoration on Soils in an Experimental Urban Forest. Ecological Applications 2021, e02336.

48. Konlan, S.S. The Potential of REDD in Ghana: A Study of the Pilot Area, Aowin Suaman District in the Western Region, Ghana. Master's Thesis, Norwegian University of Life Sciences, \AAs, 2012.

49. Garbach, K.; Milder, J.C.; Montenegro, M.; Karp, D.S.; DeClerck, F.A.J. Biodiversity and Ecosystem Services in Agroecosystems. Encyclopedia of agriculture and food systems 2014, 2, 21-40.

50. Wezel, A.; Casagrande, M.; Celette, F.; Vian, J.-F.; Ferrer, A.; Peigné, J. Agroecological Practices for Sustainable Agriculture. A Review. Agronomy for sustainable development 2014, 34, 1-20.

51. Fialho, J.S.; de Aguiar, M.I.; dos Santos Maia, L.; Magalhatilde, R.B.; de Araújo, F. das C.S.; de Oliveira, T.S. Soil Quality, Resistance and Resilience in Traditional Agricultural and Agroforestry Ecosystems in Brazils Semiarid Region. African Journal of Agricultural Research 2013, 8, 5020-5031.

52. Ramesh, T.; Manjaiah, K.M.; Mohopatra, K.P.; Rajasekar, K.; Ngachan, S.V. Assessment of Soil Organic Carbon Stocks and Fractions under Different Agroforestry Systems in Subtropical Hill Agroecosystems of North-East India. Agroforestry systems 2015, $89,677-690$.

53. Costa, E.N.D. da; Landim de Souza, M.F.; Lima Marrocos, P.C.; Lobão, D.; Lopes da Silva, D.M. Soil Organic Matter and CO2 Fluxes in Small Tropical Watersheds under Forest and Cacao Agroforestry. PloS one 2018, 13, e0200550.

54. Pransiska, Y.; Triadiati, T.; Tjitrosoedirjo, S.; Hertel, D.; Kotowska, M.M. Forest Conversion Impacts on the Fine and Coarse Root System, and Soil Organic Matter in Tropical Lowlands of Sumatera (Indonesia). Forest Ecology and Management 2016, 379, 288298.

55. El-Ramady, H.R. Integrated nutrient management and postharvest of crops. In Sustainable agriculture reviews; Springer, 2014; pp. 163-274.

56. Sommer, R.; Bossio, D.; Desta, L.; Dimes, J.; Kihara, J.; Koala, S.; Mango, N.; Rodriguez, D.; Thierfelder, C.; Winowiecki, L. Profitable and Sustainable Nutrient Management Systems for East and Southern African Smallholder Farming Systems Challenges 
and Opportunities: A Synthesis of the Eastern and Southern Africa Situation in Terms of Past Experiences, Present and Future Opportunities in Promoting Nutrients Use in Africa. 2013.

57. López-Hernández, D.; Hernández-Hernández, R.M.; Hernández-Valencia, I.; Toro, M. Nutritional Stress in Dystrophic Savanna Soils of the Orinoco Basin: Biological Responses to Low Nitrogen and Phosphorus Availabilities. In Emerging Technologies and Management of Crop Stress Tolerance; Elsevier, 2014; pp. 343-375.

58. Gaujour, E.; Amiaud, B.; Mignolet, C.; Plantureux, S. Factors and Processes Affecting Plant Biodiversity in Permanent Grasslands. A Review. Agronomy for sustainable development 2012, 32, 133-160.

59. Atangana, A.; Khasa, D.; Chang, S.; Degrande, A. Major agroforestry systems of the humid tropics. In Tropical agroforestry; Springer, 2014; pp. 49-93.

60. Jose, S. Agroforestry for Conserving and Enhancing Biodiversity. Agroforestry Systems 2012, 85, 1-8.

61. Sauer, T.J.; Coblentz, W.K.; Thomas, A.L.; Brye, K.R.; Brauer, D.K.; Skinner, J.V.; Van Brahana, J.; DeFauw, S.L.; Hays, P.D.; Moffitt, D.C. Nutrient Cycling in an Agroforestry Alley Cropping System Receiving Poultry Litter or Nitrogen Fertilizer. Nutrient cycling in agroecosystems 2015, 101, 167-179.

62. Swieter, A.; Langhof, M.; Lamerre, J.; Greef, J.M. Long-Term Yields of Oilseed Rape and Winter Wheat in a Short Rotation Alley Cropping Agroforestry System. Agroforestry Systems 2019, 93, 1853-1864.

63. Marsden, C.; Martin-Chave, A.; Cortet, J.; Hedde, M.; Capowiez, Y. How Agroforestry Systems Influence Soil Fauna and Their Functions-a Review. Plant and Soil 2020, 453, 29-44.

64. Cardinael, R.; Chevallier, T.; Barthès, B.G.; Saby, N.P.; Parent, T.; Dupraz, C.; Bernoux, M.; Chenu, C. Impact of Alley Cropping Agroforestry on Stocks, Forms and Spatial Distribution of Soil Organic Carbon - A Case Study in a Mediterranean Context. Geoderma 2015, 259, 288-299.

65. Kremer, R.J.; Kussman, R.D. Soil Quality in a Pecan-Kura Clover Alley Cropping System in the Midwestern USA. Agroforestry systems 2011, 83, 213-223.

66. Mosquera-Losada, M.R.; Freese, D.; Rigueiro-Rodríguez, A. Carbon sequestration in European agroforestry systems. In Carbon sequestration potential of agroforestry systems; Springer, 2011; pp. 43-59.

67. Wang, B.; Liu, G.; Xue, S. Effect of Black Locust (Robinia Pseudoacacia) on Soil Chemical and Microbiological Properties in the Eroded Hilly Area of China's Loess Plateau. Environmental Earth Sciences 2012, 65, 597-607.

68. Yüksek, T. The Restoration Effects of Black Locust (Robinia Pseudoacacia L) Plantation on Surface Soil Properties and Carbon Sequestration on Lower Hillslopes in the Semi-Humid Region of Coruh Drainage Basin in Turkey. Catena 2012, 90, 18-25.

69. Tsonkova, P.; Böhm, C.; Quinkenstein, A.; Freese, D. Ecological Benefits Provided by Alley Cropping Systems for Production of Woody Biomass in the Temperate Region: A Review. Agroforestry Systems 2012, 85, 133-152.

70. Aguiar, A. das C.F.; Cândido, C.S.; Carvalho, C.S.; Monroe, P.H.M.; de Moura, E.G. Organic Matter Fraction and Pools of Phosphorus as Indicators of the Impact of Land Use in the Amazonian Periphery. Ecological indicators 2013, 30, 158-164.

71. Pacheco, A.R.; Chaves, R. de Q.; Nicoli, C.M.L. Integration of Crops, Livestock, and Forestry: A System of Production for the Brazilian Cerrados. Embrapa Arroz e Feijão-Capítulo em livro científico (ALICE) 2013.

72. Peri, P.L.; Banegas, N.; Gasparri, I.; Carranza, C.H.; Rossner, B.; Pastur, G.M.; Cavallero, L.; López, D.R.; Loto, D.; Fernández, P. Carbon sequestration in temperate silvopastoral systems, Argentina. In Integrating Landscapes: Agroforestry for Biodiversity Conservation and Food Sovereignty; Springer, 2017; pp. 453-478.

73. Frison, E.A. From Uniformity to Diversity: A Paradigm Shift from Industrial Agriculture to Diversified Agroecological Systems. 2016.

74. Lopes, M.A.; Faleiro, F.G.; Ferreira, M.E.; Lopes, D.B.; Vivian, R.; Boiteux, L.S. Embrapa's Contribution to the Development of New Plant Varieties and Their Impact on Brazilian Agriculture. Crop Breeding and Applied Biotechnology 2012, 12, 31-46.

75. Bernués, A.; Ruiz, R.; Olaizola, A.; Villalba, D.; Casasús, I. Sustainability of Pasture-Based Livestock Farming Systems in the European Mediterranean Context: Synergies and Trade-Offs. Livestock Science 2011, 139, 44-57. 
76. Saljnikov, E.; Cakmak, D.; Rahimgalieva, S. Soil Organic Matter Stability as Affected by Land Management in Steppe Ecosystems. Soil processes and current trends in quality assessment 2013, 269-310.

77. Ukalska-Jaruga, A.; Klimkowicz-Pawlas, A.; Smreczak, B. Characterization of Organic Matter Fractions in the Top Layer of Soils under Different Land Uses in Central-Eastern Europe. Soil Use and Management 2019, 35, 595-606.

78. Hartley, I.P.; Hopkins, D.W.; Sommerkorn, M.; Wookey, P.A. The Response of Organic Matter Mineralisation to Nutrient and Substrate Additions in Sub-Arctic Soils. Soil Biology and Biochemistry 2010, 42, 92-100.

79. Kabiri, V.; Raiesi, F.; Ghazavi, M.A. Tillage Effects on Soil Microbial Biomass, SOM Mineralization and Enzyme Activity in a Semi-Arid Calcixerepts. Agriculture, Ecosystems \& Environment 2016, 232, 73-84.

80. Campos, A.; Suárez, G.; Laborde, J. Analyzing Vegetation Cover-Induced Organic Matter Mineralization Dynamics in Sandy Soils from Tropical Dry Coastal Ecosystems. Catena 2020, 185, 104264.

81. Geisseler, D.; Miller, K.S.; Aegerter, B.J.; Clark, N.E.; Miyao, E.M. Estimation of Annual Soil Nitrogen Mineralization Rates Using an Organic-Nitrogen Budget Approach. Soil Science Society of America Journal 2019, 83, 1227-1235.

82. Damon, P.M.; Bowden, B.; Rose, T.; Rengel, Z. Crop Residue Contributions to Phosphorus Pools in Agricultural Soils: A Review. Soil Biology and Biochemistry 2014, 74, 127-137.

83. Kallenbach, C.; Grandy, A.S. Controls over Soil Microbial Biomass Responses to Carbon Amendments in Agricultural Systems: A Meta-Analysis. Agriculture, Ecosystems \& Environment 2011, 144, 241-252.

84. Imaz, M.J.; Virto, I.; Bescansa, P.; Enrique, A.; Fernandez-Ugalde, O.; Karlen, D.L. Soil Quality Indicator Response to Tillage and Residue Management on Semi-Arid Mediterranean Cropland. Soil and Tillage Research 2010, 107, 17-25.

85. Kay, B.D. Soil Structure and Organic Carbon: A Review. Soil processes and the carbon cycle 2018, 169-197.

86. Kaleeem Abbasi, M.; Mahmood Tahir, M.; Sabir, N.; Khurshid, M. Impact of the Addition of Different Plant Residues on Nitrogen Mineralization-Immobilization Turnover and Carbon Content of a Soil Incubated under Laboratory Conditions. Solid Earth 2015, 6, 197-205.

87. Le Guillou, C.; Angers, D.A.; Maron, P.A.; Leterme, P.; Menasseri-Aubry, S. Linking Microbial Community to Soil Water-Stable Aggregation during Crop Residue Decomposition. Soil Biology and Biochemistry 2012, 50, 126-133.

88. Naresh, R.K.; Singh, S.P.; Chauhan, P. Influence of Conservation Agriculture, Permanent Raised Bed Planting and Residue Management on Soil Quality and Productivity in Maize-Wheat System in Western Uttar Pradesh. International Journal of Life Sciences, Biotechnology and Pharma Research 2012, 1, 27-34.

89. Turmel, M.-S.; Speratti, A.; Baudron, F.; Verhulst, N.; Govaerts, B. Crop Residue Management and Soil Health: A Systems Analysis. Agricultural Systems 2015, 134, 6-16.

90. Deng, L.; Zhu, G.; Tang, Z.; Shangguan, Z. Global Patterns of the Effects of Land-Use Changes on Soil Carbon Stocks. Global Ecology and Conservation 2016, 5, 127-138.

91. Wei, X.; Shao, M.; Gale, W.; Li, L. Global Pattern of Soil Carbon Losses Due to the Conversion of Forests to Agricultural Land. Scientific reports 2014, 4, 1-6.

92. Clarke, N.; Gundersen, P.; Jönsson-Belyazid, U.; Kjønaas, O.J.; Persson, T.; Sigurdsson, B.D.; Stupak, I.; Vesterdal, L. Influence of Different Tree-Harvesting Intensities on Forest Soil Carbon Stocks in Boreal and Northern Temperate Forest Ecosystems. Forest Ecology and Management 2015, 351, 9-19.

93. Luo, Z.; Wang, E.; Sun, O.J. Soil Carbon Change and Its Responses to Agricultural Practices in Australian Agro-Ecosystems: A Review and Synthesis. Geoderma 2010, 155, 211-223.

94. Gallagher, T.M.; Breecker, D.O. The Obscuring Effects of Calcite Dissolution and Formation on Quantifying Soil Respiration. Global Biogeochemical Cycles 2020, 34, e2020GB006584.

95. Jou, R.M.; Macario, K.D.; Pessenda, L.C.; Pereira, M.G.; Lorente, F.L.; Pedrosa, R.; da Silva Neto, E.C.; Fallon, S.; Muniz, M.C.; Cardoso, R.P. The Use of Carbon Isotopes $(13 \mathrm{C}, 14 \mathrm{C})$ in Different Soil Types and Vegetation Coverage in a Montane Atlantic Forest Region, Southeast Brazil. Quaternary Geochronology 2021, 61, 101133. 
96. Roy, B.; Ghosh, S.; Sanyal, P. Morpho-Tectonic Control on the Distribution of C3-C4 Plants in the Central Himalayan Siwaliks during Late Plio-Pleistocene. Earth and Planetary Science Letters 2020, 535, 116119.

97. Unkovich, M.J.; Pate, J.S.; McNeill, A.; Gibbs, J. Stable Isotope Techniques in the Study of Biological Processes and Functioning of Ecosystems; Springer Science \& Business Media, 2013; Vol. 40;.

98. Werner, C.; Schnyder, H.; Cuntz, M.; Keitel, C.; Zeeman, M.J.; Dawson, T.E.; Badeck, F.-W.; Brugnoli, E.; Ghashghaie, J.; Grams, T.E. Progress and Challenges in Using Stable Isotopes to Trace Plant Carbon and Water Relations across Scales. Biogeosciences 2012, 9, 3083-3111.

99. Negash, M.; Kanninen, M. Modeling Biomass and Soil Carbon Sequestration of Indigenous Agroforestry Systems Using CO2FIX Approach. Agriculture, Ecosystems \& Environment 2015, 203, 147-155.

100. Nowak, D.J.; Greenfield, E.J.; Hoehn, R.E.; Lapoint, E. Carbon Storage and Sequestration by Trees in Urban and Community Areas of the United States. Environmental pollution 2013, 178, 229-236.

101. Conteh, A.M.; Moiwo, J.P.; Yan, X. Using a Logistic Regression Model to Analyze Alley Farming Adoption Factors in Sierra Leone. Small-scale forestry 2016, 15, 109-125.

102. Luo, Y.; Weng, E. Dynamic Disequilibrium of the Terrestrial Carbon Cycle under Global Change. Trends in Ecology E Evolution 2011, 26, 96-104.

103. Schmitz, O.J.; Raymond, P.A.; Estes, J.A.; Kurz, W.A.; Holtgrieve, G.W.; Ritchie, M.E.; Schindler, D.E.; Spivak, A.C.; Wilson, R.W.; Bradford, M.A. Animating the Carbon Cycle. Ecosystems 2014, 17, 344-359.

104. Dutcher, B.; Fan, M.; Russell, A.G. Amine-Based CO2 Capture Technology Development from the Beginning of 2013॰ A Review. ACS applied materials $\mathcal{E}$ interfaces 2015, 7, 2137-2148.

105. Holtsmark, B. Quantifying the Global Warming Potential of CO2 Emissions from Wood Fuels. Gcb Bioenergy 2015, 7, $195-206$.

106. Goeppert, A.; Czaun, M.; Prakash, G.S.; Olah, G.A. Air as the Renewable Carbon Source of the Future: An Overview of CO 2 Capture from the Atmosphere. Energy E Environmental Science 2012, 5, 7833-7853.

107. Manisalidis, I.; Stavropoulou, E.; Stavropoulos, A.; Bezirtzoglou, E. Environmental and Health Impacts of Air Pollution: A Review. Frontiers in public health 2020, 8.

108. Anderson, T.R.; Hawkins, E.; Jones, P.D. CO2, the Greenhouse Effect and Global Warming: From the Pioneering Work of Arrhenius and Callendar to Today's Earth System Models. Endeavour 2016, 40, 178-187.

109. McCulloch, M.; Falter, J.; Trotter, J.; Montagna, P. Coral Resilience to Ocean Acidification and Global Warming through PH Up-Regulation. Nature Climate Change 2012, 2, 623-627.

110. Mohajan, H.K. Greenhouse Gas Emissions, Global Warming and Climate Change. In Proceedings of the 15th Chittagong Conference on Mathematical Physics, 2017. Jamal Nazrul Islam Research Centre for Mathematical and Physical Sciences (JNIRCMPS); $2017 ;$ p. 3.

111. TANG, Q.; CHEN, C.-T.A.; YU, K.; DAI, M.; ZHAO, M.; KE, C.; Wong, G.T.; CHAI, F.; WEI, G.; ZHOU, L. The Effects of Ocean Acidification on Marine Organisms and Ecosystem. Chinese Science Bulletin 2013, 58, 1307-1314.

112. Buth, J.M. Ocean Acidification: Investigation and Presentation of the Effects of Elevated Carbon Dioxide Levels on Seawater Chemistry and Calcareous Organisms. Journal of Chemical Education 2016, 93, 718-721.

113. Drupp, P.S.; De Carlo, E.H.; Mackenzie, F.T. Porewater CO2-Carbonic Acid System Chemistry in Permeable Carbonate Reef Sands. Marine Chemistry 2016, 185, 48-64.

114. Pires, J.C.M.; Martins, F.G.; Alvim-Ferraz, M.C.M.; Simões, M. Recent Developments on Carbon Capture and Storage: An Overview. Chemical engineering research and design 2011, 89, 1446-1460.

115. Raza, A.; Gholami, R.; Rezaee, R.; Rasouli, V.; Rabiei, M. Significant Aspects of Carbon Capture and Storage-A Review. Petroleum 2019, 5, 335-340.

116. Gaur, N.; Narasimhulu, K.; PydiSetty, Y. Recent Advances in the Bio-Remediation of Persistent Organic Pollutants and Its Effect on Environment. Journal of cleaner production 2018, 198, 1602-1631. 
117. Leung, D.Y.; Caramanna, G.; Maroto-Valer, M.M. An Overview of Current Status of Carbon Dioxide Capture and Storage Technologies. Renewable and Sustainable Energy Reviews 2014, 39, 426-443.

118. Hu, G.; Li, Y.; Ye, C.; Liu, L.; Chen, X. Engineering Microorganisms for Enhanced CO2 Sequestration. Trends in biotechnology 2019, 37, 532-547.

119. Hügler, M.; Sievert, S.M. Beyond the Calvin Cycle: Autotrophic Carbon Fixation in the Ocean. Annual review of marine science 2011, 3, 261-289.

120. Brouns, K.; Verhoeven, J.T.; Hefting, M.M. The Effects of Salinization on Aerobic and Anaerobic Decomposition and Mineralization in Peat Meadows: The Roles of Peat Type and Land Use. Journal of environmental management 2014, 143, 44-53.

121. Raven, J.A. Praeger Review: Effects on Marine Algae of Changed Seawater Chemistry with Increasing Atmospheric CO 2. In Proceedings of the Biology and Environment: Proceedings of the Royal Irish Academy; JSTOR, 2011; pp. 1-17.

122. Koçar, G.; Civaş, N. An Overview of Biofuels from Energy Crops: Current Status and Future Prospects. Renewable and Sustainable Energy Reviews 2013, 28, 900-916.

123. Valentine, J.; Clifton-Brown, J.; Hastings, A.; Robson, P.; Allison, G.; Smith, P. Food vs. Fuel: The Use of Land for Lignocellulosic ‘next Generation'Energy Crops That Minimize Competition with Primary Food Production. Gcb Bioenergy 2012, 4, 1-19.

124. Graves, C.; Ebbesen, S.D.; Mogensen, M.; Lackner, K.S. Sustainable Hydrocarbon Fuels by Recycling CO2 and H2O with Renewable or Nuclear Energy. Renewable and Sustainable Energy Reviews 2011, 15, 1-23.

125. Raheem, A.; Azlina, W.W.; Yap, Y.T.; Danquah, M.K.; Harun, R. Thermochemical Conversion of Microalgal Biomass for Biofuel Production. Renewable and Sustainable Energy Reviews 2015, 49, 990-999.

126. Hyseni, S. Carbon Capture and Storage as a Method to Mitigate Climate Change. Inquiries Journal 2017, 9.

127. Das, S.K. Carbon Sequestration and Climate Change. 2015.

128. Ussiri, D.A.; Lal, R. Carbon Sequestration for Climate Change Mitigation and Adaptation; Springer, 2017;

129. Alves, E.Q.; Macario, K.; Ascough, P.; Bronk Ramsey, C. The Worldwide Marine Radiocarbon Reservoir Effect: Definitions, Mechanisms, and Prospects. Reviews of Geophysics 2018, 56, 278-305.

130. Cheah, W.Y.; Show, P.L.; Chang, J.-S.; Ling, T.C.; Juan, J.C. Biosequestration of Atmospheric CO2 and Flue Gas-Containing CO2 by Microalgae. Bioresource technology 2015, 184, 190-201.

131. Nielsen, U.N.; Ayres, E.; Wall, D.H.; Bardgett, R.D. Soil Biodiversity and Carbon Cycling: A Review and Synthesis of Studies Examining Diversity-Function Relationships. European Journal of Soil Science 2011, 62, 105-116.

132. Asner, G.P.; Clark, J.K.; Mascaro, J.; Galindo García, G.A.; Chadwick, K.D.; Navarrete Encinales, D.A.; Paez-Acosta, G.; Cabrera Montenegro, E.; Kennedy-Bowdoin, T.; Duque, Á. High-Resolution Mapping of Forest Carbon Stocks in the Colombian Amazon. Biogeosciences 2012, 9, 2683-2696.

133. Sayre, R. Microalgae: The Potential for Carbon Capture. Bioscience 2010, 60, 722-727.

134. Johnson, M.G. The role of soil management in sequestering soil carbon. In Soil management and greenhouse effect; CRC Press, 2018; pp. 351-364.

135. Schrumpf, M.; Kaiser, K.; Guggenberger, G.; Persson, T.; Kögel-Knabner, I.; Schulze, E.-D. Storage and Stability of Organic Carbon in Soils as Related to Depth, Occlusion within Aggregates, and Attachment to Minerals. Biogeosciences 2013, 10, 1675-1691.

136. Reichstein, M.; Bahn, M.; Ciais, P.; Frank, D.; Mahecha, M.D.; Seneviratne, S.I.; Zscheischler, J.; Beer, C.; Buchmann, N.; Frank, D.C. Climate Extremes and the Carbon Cycle. Nature 2013, 500, 287-295.

137. MacBean, N.; Peylin, P. Agriculture and the Global Carbon Cycle. Nature 2014, 515, 351-352.

138. Gougoulias, C.; Clark, J.M.; Shaw, L.J. The Role of Soil Microbes in the Global Carbon Cycle: Tracking the below-Ground Microbial Processing of Plant-Derived Carbon for Manipulating Carbon Dynamics in Agricultural Systems. Journal of the Science of Food and Agriculture 2014, 94, 2362-2371. 
139. Bendtsen, J.; Delille, B.; Dieckmann, G.S.; Glud, R.N.; Kennedy, H.; Mortensen, J.; Papadimitriou, S.; Thomas, D.N.; Tison, J.-L. Sea Ice Contribution to the Air-Sea CO2 Exchange in the Arctic and Southern Oceans. Tellus B: Chemical and Physical Meteorology 2011, $63,823-830$.

140. Salas Castelo, E.M. The Role of Factors That Influence the Adoption of the Australian Carbon Farming Initiative-Emissions Reduction Fund: A Mixed Methods Study. PhD Thesis, James Cook University, 2017.

141. Liu, T.; Bruins, R.J.; Heberling, M.T. Factors Influencing Farmers' Adoption of Best Management Practices: A Review and Synthesis. Sustainability 2018, 10, 432.

142. Valdivia, C.; Barbieri, C.; Gold, M.A. Between Forestry and Farming: Policy and Environmental Implications of the Barriers to Agroforestry Adoption. Canadian Journal of Agricultural Economics/Revue canadienne d'agroeconomie 2012, 60, 155-175.

143. Conant, R.T.; Ogle, S.M.; Paul, E.A.; Paustian, K. Measuring and Monitoring Soil Organic Carbon Stocks in Agricultural Lands for Climate Mitigation. Frontiers in Ecology and the Environment 2011, 9, 169-173.

144. Funk, J.M.; Field, C.B.; Kerr, S.; Daigneault, A. Modeling the Impact of Carbon Farming on Land Use in a New Zealand Landscape. Environmental science E policy 2014, 37, 1-10.

145. Toensmeier, E. The Carbon Farming Solution: A Global Toolkit of Perennial Crops and Regenerative Agriculture Practices for Climate Change Mitigation and Food Security; Chelsea Green Publishing, 2016;

146. Ingram, J.; Mills, J.; Dibari, C.; Ferrise, R.; Ghaley, B.B.; Hansen, J.G.; Iglesias, A.; Karaczun, Z.; McVittie, A.; Merante, P. Communicating Soil Carbon Science to Farmers: Incorporating Credibility, Salience and Legitimacy. Journal of Rural Studies 2016, 48, 115-128.

147. Dhanda, K.K.; Hartman, L.P. The Ethics of Carbon Neutrality: A Critical Examination of Voluntary Carbon Offset Providers. Journal of Business Ethics 2011, 100, 119-149.

148. Macintosh, A.; Waugh, L. An Introduction to the Carbon Farming Initiative: Key Principles and Concepts; 2012;

149. Evans, M.C.; Carwardine, J.; Fensham, R.J.; Butler, D.W.; Wilson, K.A.; Possingham, H.P.; Martin, T.G. Carbon Farming via Assisted Natural Regeneration as a Cost-Effective Mechanism for Restoring Biodiversity in Agricultural Landscapes. Environmental Science \& Policy 2015, 50, 114-129.

150. Narassimhan, E.; Gallagher, K.S.; Koester, S.; Alejo, J.R. Carbon Pricing in Practice: A Review of Existing Emissions Trading Systems. Climate Policy 2018, 18, 967-991.

151. Alexander, P.; Paustian, K.; Smith, P.; Moran, D. The Economics of Soil C Sequestration and Agricultural Emissions Abatement. Soil 2015, 1, 331-339.

152. Renwick, A.; Ball, A.S.; Pretty, J.N. Economic, biological and policy constraints on the adoption of carbon farming in temperate regions. In Capturing Carbon and Conserving Biodiversity; Routledge, 2013; pp. 197-218.

153. Kragt, M.E.; Dumbrell, N.P.; Blackmore, L. Motivations and Barriers for Western Australian Broad-Acre Farmers to Adopt Carbon Farming. Environmental Science \& Policy 2017, 73, 115-123.

154. Lo, A.Y. Challenges to the Development of Carbon Markets in China. Climate Policy 2016, 16, 109-124.

155. Tesfahunegn, G.B. Farmers' Perception on Land Degradation in Northern Ethiopia: Implication for Developing Sustainable Land Management. The Social Science Journal 2019, 56, 268-287.

156. Wang, X.; VandenBygaart, A.J.; McConkey, B.C. Land Management History of Canadian Grasslands and the Impact on Soil Carbon Storage. Rangeland Ecology \& Management 2014, 67, 333-343.

157. Green, J.F. Private Standards in the Climate Regime: The Greenhouse Gas Protocol. Business and Politics 2010, $12,1-37$.

158. Ormond, J. New Regimes of Responsibilization: Practicing Product Carbon Footprinting in the New Carbon Economy. Economic Geography 2015, 91, 425-448.

159. Hartmann, F.; Perego, P.; Young, A. Carbon Accounting: Challenges for Research in Management Control and Performance Measurement. Abacus 2013, 49, 539-563. 
160. Renukappa, S.; Akintoye, A.; Egbu, C.; Goulding, J. Carbon Emission Reduction Strategies in the UK Industrial Sectors: An Empirical Study. International Journal of Climate Change Strategies and Management 2013.

161. Rissman, J.; Bataille, C.; Masanet, E.; Aden, N.; Morrow III, W.R.; Zhou, N.; Elliott, N.; Dell, R.; Heeren, N.; Huckestein, B. Technologies and Policies to Decarbonize Global Industry: Review and Assessment of Mitigation Drivers through 2070. Applied Energy 2020, 266, 114848.

162. Robinson, O.J.; Tewkesbury, A.; Kemp, S.; Williams, I.D. Towards a Universal Carbon Footprint Standard: A Case Study of Carbon Management at Universities. Journal of Cleaner Production 2018, 172, 4435-4455.

163. Ormond, J.; Goodman, M.K. A New Regime of Carbon Counting: The Practices and Politics of Accounting for Everyday Carbon through CO2e. Global Environmental Change 2015, 34, 119-131.

164. Boot-Handford, M.E.; Abanades, J.C.; Anthony, E.J.; Blunt, M.J.; Brandani, S.; Mac Dowell, N.; Fernández, J.R.; Ferrari, M.-C.; Gross, R.; Hallett, J.P. Carbon Capture and Storage Update. Energy \& Environmental Science 2014, 7, 130-189.

165. Haslam, C.; Butlin, J.; Andersson, T.; Malamatenios, J.; Lehman, G. Accounting for Carbon and Reframing Disclosure: A Business Model Approach. In Proceedings of the Accounting Forum; Taylor \& Francis, 2014; Vol. 38, pp. $200-211$.

166. Higgins, V.; Dibden, J.; Cocklin, C. Private Agri-Food Governance and Greenhouse Gas Abatement: Constructing a Corporate Carbon Economy. Geoforum 2015, 66, 75-84.

167. Torres, T.L.R. The Benevolence of Power: Advanced Liberal Government and the Carbon Subject in France's Ecological Transition. 2020.

168. Derqui, B. Towards Sustainable Development: Evolution of Corporate Sustainability in Multinational Firms. Corporate Social Responsibility and Environmental Management 2020, 27, 2712-2723.

169. McKinnon, A.C. Product-Level Carbon Auditing of Supply Chains: Environmental Imperative or Wasteful Distraction? International Journal of Physical Distribution \& Logistics Management 2010.

170. Horton, P.; Horton, B.P. Re-Defining Sustainability: Living in Harmony with Life on Earth. One Earth 2019, 1, 86-94.

171. Dauvergne, P.; Lister, J. Big Brand Sustainability: Governance Prospects and Environmental Limits. Global Environmental Change 2012, 22, 36-45.

172. Oppenheim, J.; Dyvik, C. Unleashing the power of financial markets for the green transition. In Standing up for a Sustainable World; Edward Elgar Publishing, 2020. 